\title{
From Frontier to Borderland
}

In the summer of 1595 , Nurhaci received a three-day visit from a Ming official and a Korean interpreter who had come to Fe Ala to discuss Jurchen transgressions into Chosŏn territory that had happened three years earlier. ${ }^{1}$ At the time of these transgressions, Nurhaci had complained to the Chosŏn court that when Korean soldiers arrested Jurchens for poaching ginseng in Chosŏn territory, they beheaded and even skinned them as punishment. In response to Nurhaci's complaint, the Chosŏn king, Sŏnjo (r. 1567-1608), had asked the Ming general, Yang Hao, who was in Korea at the time to deal with the Japanese invasion, to send the Jianzhou Jurchens a letter stating firmly that "the boundaries [K. ponggang] under heaven should be clearly demarcated and therefore you should not dare to covertly communicate with Koreans without the permission of the Heavenly Court [K. chŏnjo].”2 Three years later, when Nurhaci received his visitors in Fe Ala, he admitted that he still sought revenge for the Korean soldiers' excessive behavior. But he also added that "since the Ming persuaded the Chosŏn to send an official to me, I hope to maintain a friendly relationship with you." He blamed the twentyseven Jurchens who had violated Chosŏn territory for risking their own lives and promised that in the future Jurchen trespassers would be most severely punished at his own hand. Then he treated his Korean guests to a good meal. ${ }^{3}$

Nurhaci had to put up with his own people being treated as "barbarous wild people," but his successor, Hong Taiji, did not tolerate such humiliation in his relations with the Ming or the Chosŏn. After establishing his superior standing to the Chosŏn with the successful military campaign of 1627 , the khan of the Aisin Gurun began to press the Chosŏn to stop Koreans from entering Jurchen territory to collect ginseng. In his letter to the Chosŏn king Injo (r. 1623-49) in 1633, Hong 
Taiji complained that ginseng poaching by Koreans caused significant damage to the Jurchen ginseng trade:

The price of ginseng used to be set at sixteen liang per jin. However, you are now saying, "Since we Koreans do not use ginseng, we can pay only nine liang per jin. If you Jurchens do not agree with this price, we will not trade." You are simply breaking your previous promise for the purpose of letting the price fall. You say that Koreans do not use ginseng. Then what makes your people collect useless ginseng by trespassing on and stealing from our land? ${ }^{4}$

By analyzing the incidents of trespassing and the competition for ginseng between the Aisin Gurun and the Chosŏn, this chapter addresses the transition of the Jurchen state to the Qing empire from three perspectives. First, the history of the Jurchens needs to be discussed in terms of their dual relations with the Ming and the Chosŏn, each of whom they had been subservient to and dependent on, both politically and economically. Ming authority had reached beyond China proper to Liaodong and the Korean peninsula, so both the Jurchens and the Koreans had paid tribute to the Ming emperor. While serving the Son of Heaven, the Chosŏn court simultaneously strove to subjugate the Jurchens under its own influence. It was, in fact, trade relations that enabled the Ming and the Chosŏn to control the Jurchens. The underdeveloped economy of Jurchen society made it very dependent on commercial exchanges with the Ming Chinese and the Chosŏn Koreans, who in turn used trade as a means of curbing the unruly Jurchens. Unexpectedly, however, the resulting close economic ties helped the Jurchens grow beyond the reach of the Ming and the Chosŏn, eventually breaking up their triangular relationship.

Second, this chapter emphasizes that ginseng came to hold different meanings as the Jurchens transformed themselves into the Manchus. Ginseng used to be just one of many commercial items that the Jurchens traded with the Ming Chinese for products from China proper. Later, as the commercial value of ginseng rose, the areas where it grew became more important for Jurchen society, politics, and diplomacy. Ginseng became the symbol of the Jurchens themselves, as well as a physical marker to indicate the limits of Jurchen territory. When Hong Taiji founded the Qing dynasty and defeated the Chosŏn, he enforced the Qing monopoly on ginseng production at the Chosŏn boundary. After having established clear suzerainty over the Chosŏn court, the Qing was able to forcefully prohibit Koreans from harvesting ginseng in the areas near the Yalu River and the Changbaishan area in a manner that had previously been impossible.

Lastly, this chapter describes the transformation of the Jurchen-Chosŏn frontier to the Qing-Chosŏn borderland. The Liaodong region under Ming rule offers a typical case study of a frontier at which the ethnic lines between people were not clearly defined. The establishment of the Aisin Gurun, however, put an end to the tolerance for such vagueness at the Liaodong frontier. Hong Taiji sought to build 
a country whose boundaries with its neighbors were clearly marked. Nonetheless, he did not manage to establish a clear line between Chosŏn territory and his own; instead, his successors inherited a borderland, a site of more pronounced demarcation but still with a certain ambiguity.

\section{THE LIAODONG FRONTIER AND GINSENG}

During the Ming dynasty, various Jurchen groups lived scattered throughout a vast region stretching from the Heilongjiang River in the north to the Liaodong and Korean peninsulas in the south, and from Shanhaiguan in the west to the East Sea in the east. This region, better known to contemporary readers as Manchuria, ${ }^{5}$ is surrounded by three mountain ranges: the Great Xing'an in the west, the Lesser Xingan in the north, and Changbai in the east. The Argun River flows from the northwest of the Great Xingan Mountains, passing Inner Mongolia to meet the Heilongjiang and merging with the Ussuri River to flow into the Sea of Okhotsk. The Heilongjiang divides Manchuria from Russia, and the Tumen serves as its boundary with Korea. ${ }^{6}$ This huge region is also divided into four zones by geographic features and primary economic characteristics. The first zone is the lower Liao River plain, a region with rich and fertile soil suitable for agriculture and primarily populated by Han Chinese. This plain is linked to northern China by Shanhaiguan at the eastern end of the Great Wall. The second zone is the western steppe of the Liao River (Liaoxi), the area near the Great Xing'an range and the western part of Jilin and Liaoning. It is a semiarid region, with twelve inches of precipitation per year. This region is the home of pastoral nomads, who originated on the Mongolian steppe but later established a close relationship with the farmers of the Liao River plain. The third and largest zone includes the heavy forests bordering Korea and Siberia, where the local people developed a mixed economy of stock raising and agriculture. Hunting fur-bearing animals was also an important business in the forest areas near the mountain ranges. Lastly, there is a maritime coastal zone in the far north, near the Heilongjiang and the Ussuri. This northern region has rich land, but its severe winters allow only hunting and fishing, not agriculture.?

Another name for the Jurchen homeland was Liaodong, literally meaning "east of the Liao River." The geographical boundaries of Liaodong had, in fact, changed over time, reflecting the historical development of relations between the people in China proper and those living on the frontier. During the Warring States period (403-221 BCE), when the Yan dynasty established an administrative site in Liaoyang and sought to check raids by the local people, the name Liao indicated the contemporary Liaoning Province. In 668, when the early Tang ruler subjugated the Koguryŏ, one of the three kingdoms in Korea, the northeastern frontier, in addition to the northern part of the Korean peninsula, was put under the control of 
the Andong commander (Andong duhufu). At this point, Liaodong encompassed a broad swath of the northeast frontier beyond Shanhaiguan, not just the narrow district of Liaodong. When the Liao (916-1125) and successive Jin (1114-1234) dynasties ruled this area, the name Liaodong became widely used to indicate a broad region comprising three contemporary northeastern provinces. During the Yuan period (1206-1391), the name Northeast (Dongbei) first came to signify not only a geographical direction-the northeast of the center-but also a region with its own characteristics and significance. Under Ming rule, the Liaodong frontier was set apart from China proper by Shanhaiguan and was therefore often called "east of the pass" (guandong), "outside the pass" (guanwai), or "east of the Liao River" (Liaozuo). ${ }^{8}$ The Liaodong frontier discussed in this chapter generally refers to the southern part of Manchuria.

Of the many natural resources available in Liaodong, the most prominent was ginseng. Growing between 30 and 48 degrees north latitude, it is found in Changbaishan, Jilin, and Heilongjiang in China, in present-day Primorsky Krai in Russia, and throughout the entire Korean peninsula. It is all the more valuable when found in the wild, where it grows much more slowly than cultivated ginseng. ${ }^{9}$ Ginseng lives indefinitely, with only its leaves dying at the end of every season. After the leaves die, a bud scar is left on the neck of the root; this marker serves as the basis for estimating the plant's age. Age is the defining factor in determining the value of ginseng: the older it is, the more expensive it will be..$^{10}$ The shape of the plant is another important characteristic. The significant resemblance of ginseng to the human figure, especially the torso and legs, gave it names such as "man-shaped root" or "man-root." The Annotated Collections of Materia Medica (Bencao jing jizhu), a Chinese medical book written in the late fifth century, emphasizes the visual similarity of ginseng and the human body as the key element of the root's medical efficacy: "Ginseng is also called the mysterious root [shencao] or the energy of the earth [tujing]. . . . The one that resembles the human figure is particularly miraculous [youshen]." "11 Folklore holds that the more the root resembles a human shape, the more potent its healing properties and the greater its worth. ${ }^{12}$

The medical efficacy of ginseng has a long reputation in East Asia. ${ }^{13}$ It is well known that the first emperor of the Qin dynasty, who sought longevity and immortality, dispatched a group of three thousand young men and women to the mountains of a remote eastern area that produced the "divine herb." This area was later assumed to have been located either in Japan or on Cheju Island in Korea, and the herb they were searching for was ginseng. Taoism and Buddhism, both having great influence, considered the medical effects of ginseng a great mystery. An early Chinese medical book, the Compendium of Materia Medica (Bencao gangmu), introduced the medical potency of ginseng in this way:

In order to test for the true ginseng, two persons walk together, one with a piece of ginseng root in his mouth and the other with his mouth empty. If at the end of three 


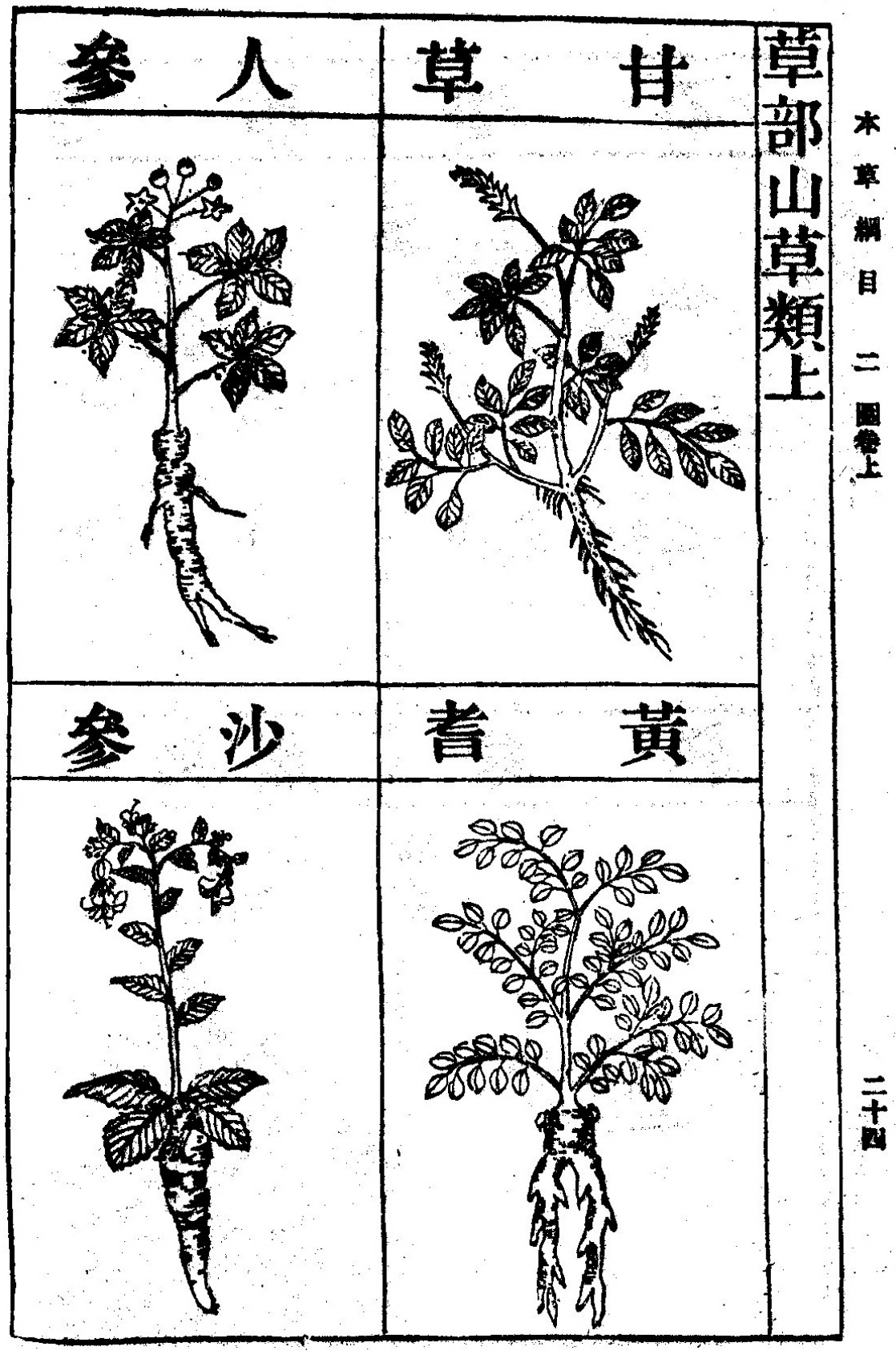

FIGURE 1. Ginseng. From Li Shizhen, Bencao gangmu (Compendium of Materia Medica), (Taipei: Shangwuyin shuguan, 1968), juan 2, tu, juan shang, 24. 
to five $l i$, the one with ginseng in his mouth does not feel himself tired, while the other is out of breath, that is genuine ginseng root. ${ }^{14}$

By the seventeenth century, knowledge of ginseng's medical efficacy had also spread to Europe via Jesuit missionaries. Notably, the French priest Pierre Jartoux (1680-1720), who accompanied an imperial tour to Manchuria, reported on the antifatigue properties of ginseng as "a sovereign remedy for all weakness occasioned by excessive fatigues either of body or mind." ${ }^{15}$

Due to its medical efficacy, mysterious age, rarity, and physical features, ginseng has always been a favorite subject of folktales and legends. ${ }^{16}$ According to these tales, ginseng can transform itself into a human being or an animal such as a tiger or a bird. Ginseng is believed to have various means of self-protection in order to evade discovery by humans, such as the ability to multiply the number of plants that look similar to it. Folktales also connect ginseng to tigers, which are thought to protect the roots, a story that makes sense because ginseng and tigers are the two symbols of Manchuria. ${ }^{17}$ All of these legends about ginseng's medical efficacy and extreme rarity demonstrate the high respect ginseng has commanded over the centuries.

By the Song period (960-1126), the ginseng consumed in China proper came largely from the area of Shangdang in Shanxi or from the Korean peninsula. It was not until the Liaodong people founded the Liao and Jin dynasties that Liaodong ginseng became more widely known. The Jurchens lived in the areas surrounded by deep forests - in particular Changbaishan-where ginseng mostly grew, so they gathered it to pay as taxes or to trade. Especially during the Jin dynasty, ginseng gathering was extended to the areas of Kaiyuan and Liaoyang. When the Mongols defeated the Jin in 1234 and the Jurchen trade in ginseng also declined, ginseng consumers in China proper had to depend on the Korean supply. ${ }^{18}$ Later, in the Ming period, ginseng from Shangdang was overexploited and replaced with roots from Liaodong, which were considered to have higher medical potency. Manchurian ginseng subsequently achieved its greatest fame during the Ming and Qing periods, and all the state policies regarding ginseng production, collection, and trade were directed at this region. ${ }^{19}$

\section{THE JURCHENS IN MING CHINA'S NORTHEAST}

When the Ming dynasty defeated the Mongols and claimed China proper, Liaodong was largely occupied by Jurchen and Mongol populations. ${ }^{20}$ The Ming distinguished between three groups of Jurchens-the Wild Jurchens, the Haixi Jurchens, and the Jianzhou Jurchens-but collectively called them "wild people" (yeren). ${ }^{21}$ The Wild Jurchens, whose name arguably came from their inferior cultural status vis-à-vis the two other groups, included various tribes such as the 
Hūrha, the Weji (or Udike), and the Warka. The Haixi Jurchens were named after the Sungari (Songhua) River, which was previously called the Haixi River. They were scattered south of the Heilongjiang, east of the Nonni River, and along the various tributaries of the Sungari River, where the Mongols' cultural influence remained strongest. ${ }^{22}$ The last group, the Jianzhou Jurchens, occupied the area near the Mudan River, Ningguta, Sanxing (Yilan), and Changbaishan, making their living through pearl and ginseng gathering, spinning, and weaving. They mixed with Han Chinese and Koreans and were therefore more exposed to agriculture and a sedentary lifestyle. ${ }^{23}$

The Jurchen populations in Liaodong were placed under the loose control of the Ming regional military commission of Liaodong (Liaodong duzhihui shisi), which was established in Liaoyang after the Ming armies defeated the Mongols in Liaodong in $1371 .^{24}$ The Ming authorities established Jurchen guards (wei) and posts (suo) and granted Jurchen tribal rulers a variety of official titles, such as regional military commissioner (duzhihuishi) and battalion commander (qianhu), along with certificates (luyin) that allowed these individuals to visit Beijing to pay tribute. The Jianzhou Jurchens were one of the early Jurchen groups who were incorporated into the Ming guard and post system in $1403 .{ }^{25}$ The local peoples living along the Heilongjiang, Sungari, and Ussuri Rivers, falling outside the jurisdiction of the Liaodong military commission, were put under the Nurgan regional military commission (Nurgan duzhihui shisi), which was established in 1409. After the first quarter of the fifteenth century, however, the Nurgan military commission existed in name only. By the late sixteenth century, the number of Jurchen guards and posts under the Liaodong military commission had increased to as many as 384 guards and twenty-four posts. ${ }^{26}$

The Liaodong Frontier Wall (bianqiang) served as the physical barrier separating the Liaodong military commission from the areas outside of its control. The wall stretched from Shanhaiguan to Kaiyuan and southward to the Yalu River, with a total length of two thousand $l i$ and the shape of the roman letter $M$. The western side of the wall was built first, with the purpose of fending off the Uriangkha (Wuliangha) and other Mongol tribes; the eastern length was built later to control the Jianzhou and Haixi Jurchens. Seven passes (kou) and ninety-two posts (bao) were built along the wall for the purpose of designating areas for Han Chinese, Mongols, and Jurchens and to protect China proper from the frontier tribes. Each group of Mongols and Jurchens was assigned a specific location and a time for its visit to Ming territory. ${ }^{27}$ In fact, as Inaba Iwakichi has pointed out, it is doubtful whether the Ming authorities were truly capable of ruling the whole area in which they granted titles; it is more likely that Han Chinese had largely lived in the areas between Fushun, Qinghe, and Lianshanguan, so the Ming people considered Lianshanguan "a boundary between the civilized and the uncivilized." ${ }^{28}$ As this remark explains, the presence of Ming guards and posts did not necessarily mean that 
the Ming had full authority over the Jurchens or Mongols in the area. Instead, the tribal leaders presented tributes and followed the proper rituals at the Ming court in exchange for receiving official titles, which in turn provided them with access to Ming markets and commercial privileges. Beyond the Liaodong Frontier Wall lay the outside of the Ming realm (bianwai), and the wall was a visible indicator of the limits of Ming power in Liaodong. ${ }^{29}$

The primary reason for Jurchen and Mongol recognition of Ming authority in Liaodong was the economic benefits that accompanied the tributary relationship with the Ming. Every year, a thousand Haixi Jurchens and five hundred Jianzhou Jurchens traveled to Kaiyuan to present to the Ming emperor their local products, including horses, sable skins, gyrfalcons, wax, walrus teeth, and ginseng. ${ }^{30}$ In return, they were awarded silk and gifts, whose amounts depended on their ranks and official titles. These presents from the Ming court were usually more valuable than the tributes offered by the Jurchens, so the Jurchen rulers were able to realize huge profits from their visits to Beijing. By the late sixteenth century, the presents were given in silver, not in kind, an important change that brought even more benefits to the Jurchen visitors and thus further fueled competition among tribal rulers for an invitation from the emperor. ${ }^{31}$

Private trade at frontier markets was another type of economic benefit that the Jurchens enjoyed as a result of their relationship with the Ming. Since the number of Jurchen visitors to Beijing and the value of the Ming presents they received were always limited, the Jurchens wanted access to markets near their residence. The first market for the Jurchens was opened in Ming Liaodong in 1405. It was often called the "horse market" (mashi) or "timber market" (mushi), although trading items also included Chinese iron products and agricultural tools, Jurchen ginseng and furs, and Mongol horses and oxen. ${ }^{32}$ By the end of the Ming era, there were a total of fourteen such markets, of which those in Guangning, Kaiyuan, and Fushun were the biggest. Each tribal group was assigned a specific place to trade. ${ }^{33}$ All of these markets were built at strategically important passes along the Liaodong Frontier Wall; they were placed near fortresses, with city walls and a watchtower, and in locations where grass and water were available for animals. Special "officials of the horse market" (mashiguan) were appointed to three-year positions and commissioned to manage the trade. Able to speak both Chinese and local languages, these officials were usually appointed from among local tribal leaders and were given a Ming title. The Ming thereby sought to regulate the duration of the markets; for example, once a month for five days in Kaiyuan, and twice a month for five days each time in Guangning. However, by the mid-sixteenth century, such regulations were not respected at all. The Kaiyuan market, for instance, was open every three days or even every other day, and the number of visitors was not limited. ${ }^{34}$

It was Manchurian natural resources that the Jurchens brought to the markets for trading with Ming Chinese. Starting with the reign of Chenghua (1465-87), an 
increasing number of records attest to Jurchen leaders visiting the Ming court and paying tribute in furs. As the popularity of and demand for furs increased among Han Chinese, the Ming Board of Rites assigned a certain amount of fur tributes to officials in Liaodong, who checked the Jurchen visitors and allowed them to proceed to Beijing only after their fur tributes had been approved. Chinese demand for furs grew to the point that the Ming court decided to prohibit lower-class people from wearing furs. At the end of the Ming period, fur consumption continued to increase; the Ming court was estimated to use ten thousand sable pelts and sixty thousand fox pelts per year. ${ }^{35}$ In addition to furs, Liaodong ginseng was very popular, and by the late Ming period it became the most sought-after Jurchen product at the markets. As ginseng prices continued to go up in the late sixteenth century, the Ming court directed the Liaodong commissioner to take responsibility for ginseng tributes to Beijing. This move pushed Han Chinese to go and collect ginseng in Jurchen land. Strong complaints from the Jurchens about Han Chinese ginseng exploiters led the Ming court and the Liaodong commissioner to give up their attempt to collect ginseng in Jurchen territory, but Han Chinese trespassing for ginseng remained one of the main reasons for Ming-Jurchen conflicts. ${ }^{36}$

China's high demand for furs and ginseng led to rapid growth in the number of Jurchen merchants and to substantial changes in the tribal societies. The development of frontier markets allowed the Ming authorities to amass a significant amount of tax revenue, a big portion of which was in turn gifted to Jurchen visitors. Kim Kujin's analysis of Ming records of tax collection in Liaodong shows that the value of commodities traded at frontier markets totaled 21,000 to 24,00o liang of silver. ${ }^{37}$ Ming officials in Guangning spent 4,500 liang of silver from 1599 to 1601 on various presents for Jurchen visitors, such as textiles, foodstuffs, salt, and iron products; by 1605 , this amount increased to 17,400 liang of silver. The increasing wealth of Jurchen merchants caused social differentiation among the local tribes. ${ }^{38}$ As a result, "competition for the privilege of accessing [Ming] markets led to struggles among the Jurchens, conflicts that became worse when the Ming intervened to play one tribal ruler against another." ${ }^{39}$ The rise of Nurhaci provides a good example of how rivalries for commercial profits led to the unification of local tribes at the Liaodong frontier.

\section{THE JURCHENS IN CHOSŎN KOREA'S NORTH}

The Jianzhou Jurchens in Liaodong benefited from their contacts with another sedentary neighbor-Chosŏn Korea (1392-1910). Chosŏn T’aejo Yi Sŏnggye (r. 1392-98) was born and raised in Kyŏnghŭng, where his ancestors had served the Yuan as local officials. As Songs of Flying Dragons (K. Yongbi ŏch’ŏn'ga) mythologizes, Yi Sŏnggye's great-grandfather and grandfather mingled with the Jurchens, both in trade and in war, and Yi Sŏnggye himself achieved his military reputation 
after defeating Nahacu's Mongol armies in Liaodong. ${ }^{40}$ When he established the Chosŏn dynasty, many Jurchen tribes scattered to live around the Yalu and Tumen Rivers. Unlike the Ming division of the Jurchens into the Wild, the Haixi, and the Jianzhou, the Chosŏn called them by Jurchen names, such as Uriangkha (K. Ollyanghap), Odori, and Udike. ${ }^{41}$ The Uriangkha and the Odori used to live at the convergence of the Sungari and Mudan Rivers, also known as Ilan Hala or Sanxing; later, when one of the tribal leaders, Ahacu, led his people to move to the upper Suifenhe, the Ming Yongle emperor (r. 1403-24) appointed him the Jianzhou Guard commander.42 In 1424 Ahacu's grandson, Li Manzhou, settled at the Tunggiya River, and in Chosŏn records his group is called Uriangkha. The Odori people, for their part, moved to the east and settled south of the Tumen River. The leader of the Odori was Möngke Temür, whom the Chosŏn called Tong Maengga Chŏmmoga or Kyaon Mŏngge t'emul. ${ }^{43} \mathrm{He}$ paid visits and tribute to the Chosŏn court in 1395, and in 1399 he was introduced as the head of the Odori in Omohoi (Hoeryŏng) in Hamgyŏng Province. In 1404, he was given the honorary military position of first deputy commander (K. sanghogun) by the Chosŏn court. ${ }^{44}$

By the time Möngke Temür was receiving the Chosŏn court's titles, the Ming Yongle emperor, who also sought to subjugate the Jurchens in the northeast, began to approach the Odori leader to offer him Ming printed patents (chishu) and material rewards. Yongle's open ambition to extend Ming power to the Tumen River surprised the Chosŏn court, which implicitly advised Möngke Temür not to follow the Ming, because peace in the Chosŏn realm's north was impossible without the cooperation of powerful Jurchen leaders. The close relationship of the Chosŏn with the Jurchens, however, led Yongle to doubt Korean loyalty to the Ming emperor. After serving the Chosŏn court for two decades, in 1405, Möngke Temür finally paid tribute to the Ming court and was appointed the Ming commander of the Jianzhou Left Guard (Jianzhou zuowei). ${ }^{45}$ However, as Chosŏn soldiers subsequently attacked his Odori people in revenge, Möngke Temür moved to Fengzhou and joined Li Manzhou in the Jianzhou Main Guard. In 1423 Möngke Temür managed to return to Omohoi (Hoeryŏng), but ended up being killed during internal fighting among Jurchen tribes in 1433. After Möngke Temür's death the Jianzhou Left Guard became weak and scattered, and in 1440 his brother Fanca likewise had to move to Li Manzhou of the Jianzhou Main Guard at the Tunggiya River, a place that later became the base of Nurhaci's grandfathers. Later eighteenth-century Qing court records refer to Möngke Temür as Mengtemu and describe him as the progenitor of the Manchu imperial family. ${ }^{46}$

The Unified Gazetteer of the Great Ming (Da Ming yitongzhi), published in 1461, explains that "Jurchen [territory] reached the sea in the east, Uriangkha [territory] in the west, the Chosŏn in the south, and Nurgan in the north." ${ }^{47}$ Some studies argue that the Ming lost the territory to the south of the Tumen River when Möngke Temür and his Jiangzhou Left Guard moved to the west, a retreat that made the 
Yalu and Tumen Rivers the Ming-Chosŏn boundary. ${ }^{48}$ However, it is doubtful whether the Jurchen residence could be claimed as an exclusive part of Ming territory. The Jurchens were dispersed across the Chosŏn northern provinces, an area that should be seen as an economic, political, cultural, and linguistic frontier between the Jurchens and the Koreans. ${ }^{49}$ Various other Jurchen tribes, including the Morin Uriangkha and the Udike, were spread over the vast area between the Tumen River and the Possiat Bay and had more contacts with the Chosŏn than with the Ming. They made their living through fishing, hunting, and partial agriculture, as well as food donations that they requested from the Chosŏn. ${ }^{50}$ The boundaries between the Ming, the Chosŏn, and the Jurchens were not clear-cut but rather unbounded and ambiguous; sovereignty over the Jurchen territories was overlapping and multilayered.

The Ming establishment of the Jianzhou Left Guard in 1405 did not stop Chosŏn efforts to expand northward in the area of the Yalu and Tumen Rivers. After the Morin Uriangkha and the Udike also paid visits to the Ming court in 1405-6, following the example of Möngke Temür, the Chosŏn decided to avenge their betrayal and ceased the practices of gift-giving and trading with the Jurchens. In 1410, when the Odori, the Udike, and Morin Uriangkha, feeling threatened, attacked Chosŏn territory, the Chosŏn raided their bases and killed their leaders. ${ }^{51}$ King Sejong (r. 1419-50) took even more aggressive action by building military garrisons in the north, near Jurchen territory. ${ }^{52}$ During the years 1416 to 1443, the Chosŏn established four counties (K. sagun) on the upper Yalu River: Yŏyŏn, Chasŏng, Muchang, and Wuye. Additional garrisons on the Tumen River were founded between 1434 and 1449, including Hoeryŏng, Chongsŏng, Onsŏng, Kyŏngwŏn, Kyŏnghŭng, and Punyŏng. The six garrisons (K. yukchin) on the Tumen River were deemed successful, as the fortresses "are strong and affluent; soldiers' horses are fast and tough. They may not be enough to raise armies, but they are good enough for defense." ${ }_{53}$ However, the counties on the Yalu River were not as successful as those on the Tumen because they were located very close to Jurchen bases; also, the land was barren and not suited to settlement and agriculture. By 1459, the Chosŏn court finally decided to close the counties on the upper part of the Yalu River, and this region came to be known as "the Four Closed Counties" (K. P'yesagun). ${ }^{54}$ The Chosŏn expansion toward the north was, in fact, constantly opposed by the Ming, which was wary of the possibility of KoreanJurchen collaboration and the potential threat to Ming control over Liaodong. ${ }^{55}$ Ming-Chosŏn tensions over the Jurchens in Korea's northern region remerged in the mid-fifteenth century, when the Ming found many Jurchen tribal leaders in the Changbaishan region receiving Chosonn court titles and paying visits to Korea. The Chosŏn king Sejo (r. 1455-68) was particularly eager to invite the Jurchens into his country, an action that inevitably attracted Ming attention. In 1458, when the Chosŏn court granted official titles to two of the Jianzhou Jurchen leaders, the 
Ming Tianshun emperor (r. 1457-63) accused the Chosŏn king of violating the imperial order to refrain from making contact with the Jurchens. The following year, when the Ming court discovered that the Morin Uriangkha leader, Langbo-er-han, had received an official Chosŏn title, the Ming emperor criticized the Chosŏn king for being disobedient:

The [Chosŏn] court has been a tributary [fanguo] in the east of China, being loyal and respectful since the previous court and never making contact with foreigners without permission. Then how did this happen in the current court? ... Even though [the Jurchens] approached [the Chosŏn] on their own, [the Chosŏn] should refuse [their overtures] and admonish them to do their duty, keep their boundaries, and not create any trouble or cause of regret for the future. ${ }^{56}$

Sejo was apparently angry with the Ming intervention but had to order the Jurchens not to visit Korea, because "it is not necessary to violate what the Ming has prohibited." ${ }^{57}$ Such Ming interventions in Chosŏn-Jurchen relations demonstrate that the geographical fact of the Chosŏn north's adjacency with Ming Liaodong-a crucial location for the security of China proper-played a decisive role in the formation of Ming-Chosŏn relations. In other words, the Chosŏn was able to maintain a peaceful relationship with the Ming court only by respecting the imperial authority and by keeping its distance from the Liaodong frontier.

As in their dealings with the Ming, the Jurchens expected to gain trade opportunities through their interactions with the Chosŏn. The Chosŏn policy toward the Jurchens in the north followed the Ming model, which entitled tribal rulers to visit the capital and frontier markets in exchange for the payment of tributes. The Northern Guest House (K. Pukp'yŏnggwan) was built in 1438 in the Chosŏn capital to receive Jurchen visitors, evidence that Chosŏn contact with the Jurchens had become more frequent despite the constant Ming warnings..$^{58}$ The number of visitors was, however, limited: in a good harvest year, 120 people could visit on seventeen occasions; otherwise, only ninety people were to come on twelve occasions. In order to avoid trouble with Beijing, the Jurchens were not allowed to enter Chosŏn territory at times when Ming emissaries were visiting Seoul. ${ }^{59}$ The Jurchens presented the Chosŏn court with their local products, which included horses, leopard skins, bear and deer skins, and hawks; Chosŏn return gifts were mostly cotton fabrics. ${ }^{60}$ Just as the Ming opened markets for tribespeople in Liaodong, the Chosŏn created markets for the Jurchens in the north. Markets for the Jurchens (K. yain muyŏkso) were opened in Chongsŏng and Kyŏngwŏn in 1406, ${ }^{61}$ only a year after the Ming established its first market for the Jurchens.

The Chosŏn court deemed the Jurchens living near the Tumen River Korea's "subordinate barbarians" (K. pŏnho), a name for those who lived in Chosŏn territories, submitted to Chosŏn authority, volunteered to report about the movements of other tribal peoples, and protected local Koreans from threats posed by other tribes. ${ }^{62}$ This name reveals the nature of the Chosŏn policy on the Jurchens, 
which aimed to foster peace in the north by embracing the Jurchens under Korean rule. By the early sixteenth century, the Chosonn court praised its own benevolent practices, claiming that "the barbarians living near [Chosŏn] towns have lived in our territories for generations; they have been fed and clothed whenever they suffered from hunger and coldness, and they have received Chosŏn titles and rich rewards, thanks to our generosity." ${ }^{63}$ As Kenneth Robinson puts it, "The Chosŏn court sought to restore peace and security to Korea's northern regions through a combination of diplomatic, naturalization, and trade policies." ${ }^{\prime 4}$ It is important to note here that Chosonn views on the Jurchens were largely based on the Ming model, which required foreign rulers to recognize Chinese superiority. As Chŏng Taham explains, the Chosŏn court attempted to apply its own version of a Sinocentric ideology to its inferior neighbors, namely, the Jurchens in the north, a practice that demonstrated "the construction of a multilayered hierarchy among the Ming, the Choson, and the Jurchens." ${ }^{55}$ In this tripartite relationship, the Jurchens and Koreans were both under Ming authority, while the Koreans claimed their own superiority to the Jurchens. This multilayered hierarchy provided the Jurchens with more opportunities to interact with Ming Chinese and Chosonn Koreans and, in time, to grow to the extent that they could challenge these two neighbors.

\section{THE RISE OF NURHACI}

Compared with other tribal groups in Liaodong, the Jianzhou Jurchens enjoyed geographical advantages in waging war against their rivals. First, they had close access to profitable natural resources such as ginseng, sable, and pearls. And second, unlike the Haixi Jurchens and the Uriangkha Mongols, the Jianzhou Jurchens lived close to the Ming and the Chosonn, which "gave them the leverage to demand and gain more concessions." ${ }^{\prime 66}$ The great potential for profit at the frontier markets led Jurchen leaders to compete with one another for the privilege of access, until one of them succeeded in securing a monopoly on the entire profit from trade with China. In fact, the rivalries among the Jurchen tribes in Liaodong resulted from the Ming divide-and-rule policy, which sought to divide the frontier tribesmen and prevent any one of them from becoming too powerful. The rise of Nurhaci and the subsequent unification of the Jurchen tribes were a direct result of the failure of the Ming Liaodong policy. ${ }^{67}$

Before Nurhaci established his dominance, it was the Ming military commander of Liaodong, Li Chengliang (1526-1615), who controlled the rivalries among the frontier tribesmen. ${ }^{68}$ While the Jianzhou Guard lived in the east of Liaodong, the Haixi Jurchens were forced by the Mongols to move to the area known as the four Hülun confederations, which included the Ula, the Hoifa, the Yehe, and the Hada.$^{69}$ By 1548 , the Hada chieftain Wang Tai had succeeded in subjugating all 


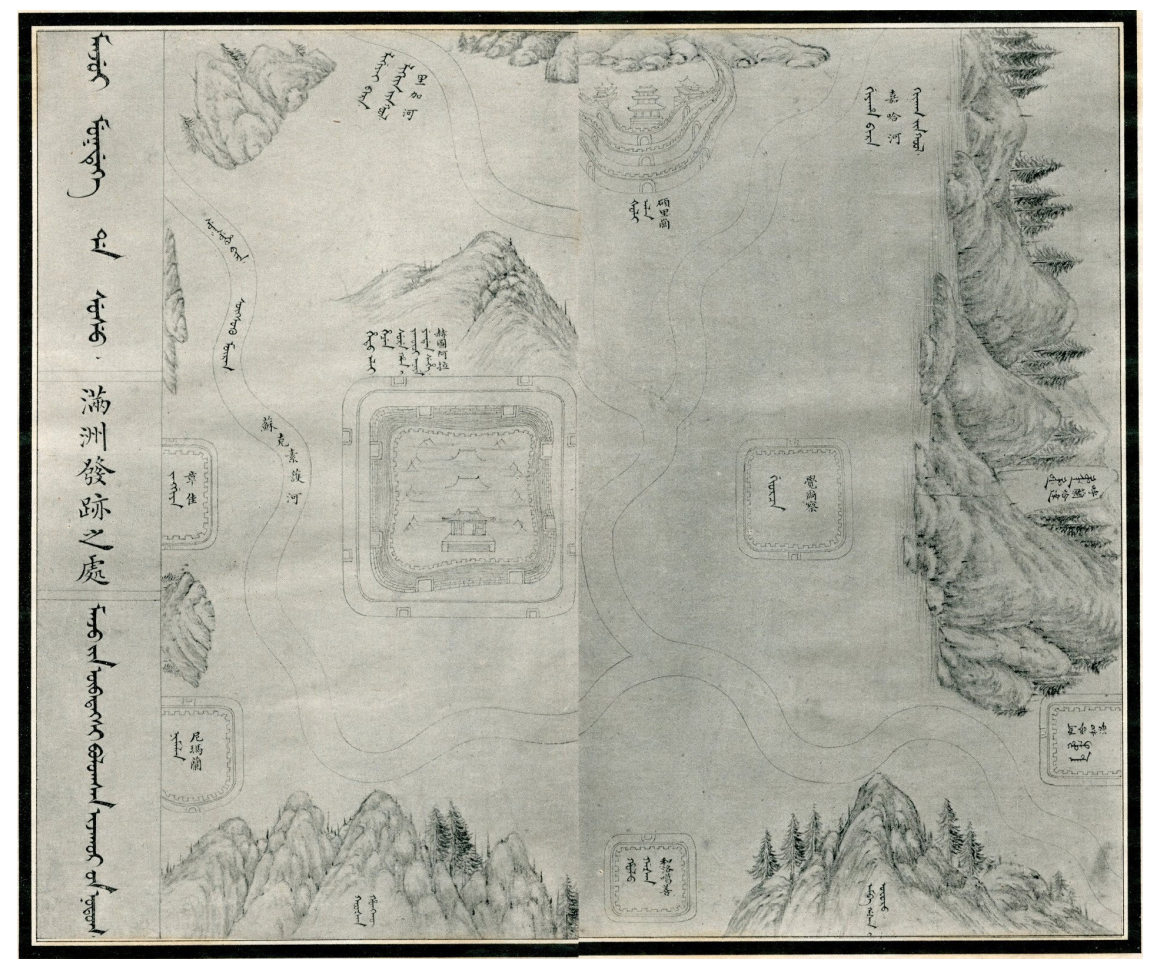

FIgURE 2. Hetu Ala and its surrounding area. From Manzhou Shilu (Manchu Veritable Record), 1779. Manuscript, $26.2 \times 15.7 \mathrm{~cm}$. Korea University Library. Used with permission.

four Hülun confederations and had expanded his power over some of the Jianzhou Jurchens as well. When Wang Gao, a leader of the Jianzhou Guard, allied with the Mongols and attacked the Ming fort in Fushun in 1573, he was captured by his rival Wang Tai and executed by Li Chengliang. Wang Gao's son, Atai, succeeded his father as ruler of the Jianzhou Jurchens; among his followers were Giocangga and Taksi, descendants of Möngke Temür and the grandfather and the father, respectively, of Nurhaci. While serving Atai, Giocangga and Taksi are also believed to have made an alliance with Li Chengliang, but they were eventually killed in the battle between Atai and Li Chengliang. ${ }^{70}$

Just like his grandfather and father, Nurhaci is believed to have been very familiar with the Ming Liaodong commander. Giocangga and Taksi were official delegates of the Jianzhou Jurchen and also merchants who frequently visited the Ming market at Fushun. Nurhaci had visited Fushun often with his grandfather and father to trade horses and other products from Jurchen territories. After the deaths of Giocangga and Taksi, Nurhaci rebuked the Ming officials in Liaodong, 
calling them "the enemy who should not share the same heaven." At the same time, however, he demanded compensation from the Ming authorities, who eventually offered him thirty printed patents and thirty horses along with the title of assistant commander in chief $(d u d u) .{ }^{11}$ Despite his constant criticism and condemnation of the Ming, Nurhaci continued to have access to Ming markets. In 1592, Nurhaci offered to send his Jurchen troops to join the Ming in their fight against the Japanese invasion of Korea. ${ }^{72}$ The Ming did not accept his offer but praised his loyalty by granting him the title of dragon-tiger general (longhu jiangjun). Nurhaci continued to hold this title, which allowed him to send his people to Beijing and to access frontier markets, until he finally renounced the relationship with the Ming court in $1608 .{ }^{73}$

Close relations with the Ming authorities and frequent access to Ming markets gave Nurhaci wealth and power. Around the middle of the sixteenth century there were many Jurchen leaders who traded at Ming markets, but Nurhaci successfully competed with the others and established his base around Fushun and Qinghe. His desire to monopolize the huge profits available at the frontier markets led him to defeat other tribes and seize all trading rights with the Ming. The Hada were the first to be subjugated, between 1599 and 1601; the Hoifa followed in 1607, the Ula in 1613 , and finally the Yehe in 1619. By defeating the Hada and the Ula, Nurhaci deprived them of their pearl and sable trade, closed the road to Kaiyuan, and instead opened a new market under his own control in Qinghe.74 Even before he defeated the Ula tribe, Nurhaci tried to intervene in Chosonn-Ula relations, suggesting that the Chosŏn should send Korean cotton fabrics to his Jianzhou Jurchens rather than to the Ula, who had been receiving this Chosŏn gift. ${ }^{75}$ Nurhaci's trading activities are well described in a Ming record, the Illustrated Writings on Kaiyuan (Kaiyuan tushuo):

The profits from ginseng, sable, and horse are all produced by the Jurchens. Some of the Jurchen merchants are coming far from the distant Sungari River and the Heilongjiang. ... Ever since Huang-hu-tai and others constructed a fort at the mouth of the Sungari River, the profits have all fallen into the hands of Nurhaci. The cause of disputes among the Jurchens every year is that they are fighting over printed patents, that is, they are fighting over commercial profits. ${ }^{76}$

The primary customers for sable fur and pearls from Liaodong were a limited number of wealthy people in Beijing and Jiangnan, while ginseng was more widely circulated thanks to its light weight. There was strong demand for this expensive commodity in China proper; one liang of ginseng cost more than one liang of silver. ${ }^{77}$ From the beginning of Nurhaci's career, the ginseng trade was very important for him. According to a folktale of his early days, Nurhaci had lost his birth mother and allegedly escaped his stepmother's abuse by fleeing to Changbaishan, where he learned about ginseng gathering and later made his living through the ginseng trade at the Ming markets. ${ }^{78}$ Another story tells us that Nurhaci taught 
his men a new method of preserving ginseng. The Jurchens usually added water to ginseng in order to make it heavier to get a higher price for it at the market. However, when Chinese traders refused to buy the soaked ginseng, Nurhaci's men lost all of the profits for ten thousand liang of ginseng. Nurhaci is believed to have found a new way of preserving ginseng by steaming and drying it, and he thus taught his people to wait for a longer time to get a good price. ${ }^{79}$ However, this story of ginseng preservation suggests that the practice of steaming and drying was already known to the locals and that Nurhaci may have merely introduced it to a broader audience among the Jurchens. ${ }^{80}$

These stories may have been created to highlight Nurhaci's enormous interest in and familiarity with the ginseng trade at the time when he became the ruler of the Jianzhou Jurchens. Nurhaci was well known for seeking exclusive profits in the trade with the Ming: "If any tribal leader was found to have traded a tiny amount of sable, pheasant, rabbit, pearls, or ginseng without Nurhaci's approval, he was executed. All the profits from trading were monopolized by Nurhaci." ${ }^{1}$ The significance of the ginseng trade for the Jurchens is also described in Qing court records: "Our country produces pearls, ginseng, and sable, and all of them are so precious that [their value is high enough] to meet our demands. [We trade them] at the four markets of Fushun, Qinghe, Kuandian, and Aiyang, contributing to the development and affluence of our people in Manchuria." ${ }^{82}$ With regard to the value of the ginseng trade, Nicola Di Cosmo has analyzed a sample of Ming records to estimate that the amount of ginseng Nurhaci traded in two years at the Ming markets was possibly as high as one hundred thousand jin, which "corresponded in value to approximately a quarter of the total foreign silver imported in China in a single year." ${ }^{3}$ As Imamura Tomo puts it, Nurhaci's ability to amass power was based not only on his military superiority but also on commercial profits from the ginseng trade. ${ }^{84}$

Nurhaci's monopoly on the Ming markets caused fundamental changes in relations among local tribes as well as tensions with the Ming authorities. The frontier markets posed a severe financial burden to the Ming authorities, who had to give gifts to the tribal leaders and purchase Jurchen products at steep prices. In 1607, when Nurhaci brought several tens of thousands of liang of ginseng to the passes near Kuandian, Aiyang, Qinghe, and Fushun, the Ming had to push Chinese soldiers and merchants to buy the Jurchen ginseng by spending their salaries or even using up their property, out of fear that the Jurchens would otherwise make trouble. ${ }^{85}$ Despite this huge burden, the Ming could not close the markets, because this would likely have triggered Jurchen raids on Ming cities. As Ming court officials lamented, "It is too much of a burden if we continue to bestow gifts on them, but it will possibly bring troubles if we [stop this practice and] fight with them. We have regretted this situation and endured it for such a long time." ${ }^{86}$ The Ming managed the markets as a defensive method of pacifying 
the frontier people, not as an aggressive means of making profits. For Nurhaci, it was the other way around: the Ming markets were the primary source of his power in Liaodong. As Iwai Shigeki puts it, "The Ming-Qing transition could be regarded as an outcome of the growth of interregional trade and the mobilization of frontier society." ${ }^{\prime 7}$

Gertraude Roth Li finds the reason for Nurhaci's contentious behavior and attitudes in his political ambitions: "Aware that both the Ming and Chosŏn governments considered the Jurchens politically as well as culturally inferior, Nurhaci, an aspiring leader, rethought his goals and decided that being a Ming official in charge of the Jianzhou Guard was not good enough." ${ }^{88}$ However, Jurchen economic concerns played an equally significant role in the formation of Nurhaci's political consciousness. As Di Cosmo points out, "From the very beginning Nurhaci's strategy aimed to control the flux of commercial products moving towards the market towns." Furthermore, "[Nurhaci's] tribute visits to the Ming court constituted important occasions to consolidate his power and retain trading privileges." ${ }^{9}$ When the Ming court sought to tighten its grip on the Jurchens for the purpose of frontier control, Nurhaci found it impossible to continue to submit to Ming supremacy. In order to maintain both the economic profits and the political power that he had achieved, he now had to challenge the Ming in Liaodong.

\section{JURCHEN BOUNDARY MAKING}

By 1589, Nurhaci had completed the unification of the Jurchen tribes and further expanded his power westward of Liaodong. He began to seek to promote the status of the Jianzhou Jurchens in relation with their neighbors, among whom the Chosŏn were the most suitable for validating his newly elevated power. In 1595, Nurhaci attempted to make direct contact with the Chosŏn, despite the Ming court's warning not to do so. In a letter written to the Manp'o commander (K. chǒmsa), Nurhaci suggested that the Jurchens and the Koreans should not violate the boundary nor harm each other..$^{90}$ When a Korean interpreter, Ha Seguk, visited Fe Ala in the summer of that year, Nurhaci proposed an official letter exchange to the Chosŏn court. ${ }^{91}$ Later, when the Manpo commander, Sin Ch'ungil, visited Fe Ala, Nurhaci again expressed his desire to establish an official relationship with the Chosŏn. Sin Ch'ungil assumed that Nurhaci simply wanted to "demonstrate his close relations with the superior country [the Ming] and with us [the Chosŏn] in order to subjugate [his rival] barbarians [K. hoin]." ${ }^{22}$ A decade later, however, Nurhaci began to indicate greater distance from the Ming by discarding his previous title as the head of the Jianzhou Jurchen guard. ${ }^{93}$ In a letter to the Manpo commander in 1605, he called himself "King of the Jianzhou region, Tong" (Jianzhou dengchu difang 
guowang Tong). In this letter, Nurhaci warned the Chosŏn king to adhere strictly to his boundaries:

Since the Koryŏ [Chosŏn] is known for its richness in ginseng, people ride horses and go around the mountains looking for ginseng.... If you Koreans cross the river, I will arrest and kill you. If our people cross the river, you can arrest and kill them. This will make things even. If you arrest our people who cross the river and send them back to me, I will kill them. It will be my fault if I do not kill them. ${ }^{94}$

By 1607 , Nurhaci's power reached further toward Chosŏn territory, as he had conquered the Weji tribe in the East Sea region (Donghai woji) north of the Tumen River. In 1609, Nurhaci's forces launched a major attack on the Ula in the battle of Munam near Chongsŏng, a move that positioned the Jianzhou Jurchens much closer to Chosŏn territory. ${ }^{95}$ The same year, Nurhaci claimed that the Warka tribe, which lived in the northern part of Chosŏn territory, should be under his command, and he therefore asked the Ming emperor to force the Chosŏn court to send these people back to him. In the end, the Chosŏn had to send one thousand Warka households to Nurhaci. ${ }^{96}$

Nurhaci's efforts to expand his power led him to seek clear divisions between Jurchen territory and its neighbors. The agreement reached in 1608 between the Ming and Nurhaci was, in fact, a temporary consensus regarding the boundaries of the Jurchen tribes. After watching the Jianzhou Jurchens subjugate the Hada and the Hoifa, the Ming Liaodong officials were eager to confirm the boundaries of Nurhaci's power. The agreement, which entailed the erection of a stone marker and the sacrifice of a white horse, stipulated that the two groups should not violate each other's territories: "Whether they are Jurchens or Han Chinese, any trespassers caught should be killed without pardon. Local officials who do not kill trespassers should also be punished." ${ }^{97}$ The inscription on the stone marker that Nurhaci and Ming Liaodong officials had built states, "You are China [Zhongguo], and we are a foreign country [waiguo]. The two big countries [daguo] are as close as one family." ${ }^{8}$ This message shows that by the early seventeenth century Ming officials recognized that they now shared Liaodong with Nurhaci.

In 1616, Nurhaci finally announced the creation of the Jurchen state, the Aisin Gurun. When the Ming closed its markets as punishment for this challenge to the emperor, Nurhaci proclaimed a list of seven vexations with the Ming before launching a series of attacks on Ming fortresses in Liaodong. ${ }^{99}$ He succeeded in capturing Tieling and Kaiyuan in 1619, Fushun in 1620, and Shenyang and Liaoyang in 1621. In the 1620 s, Nurhaci announced that limits of his country "reach the sea in the east, the Liaodong boundaries with the Ming in the west, the Korchin Mongols near the Nonni River in the north, and Chosŏn boundaries in the south." Of people living within this area, "those who share the same language as the Jurchens are all subjugated [to us]."100 


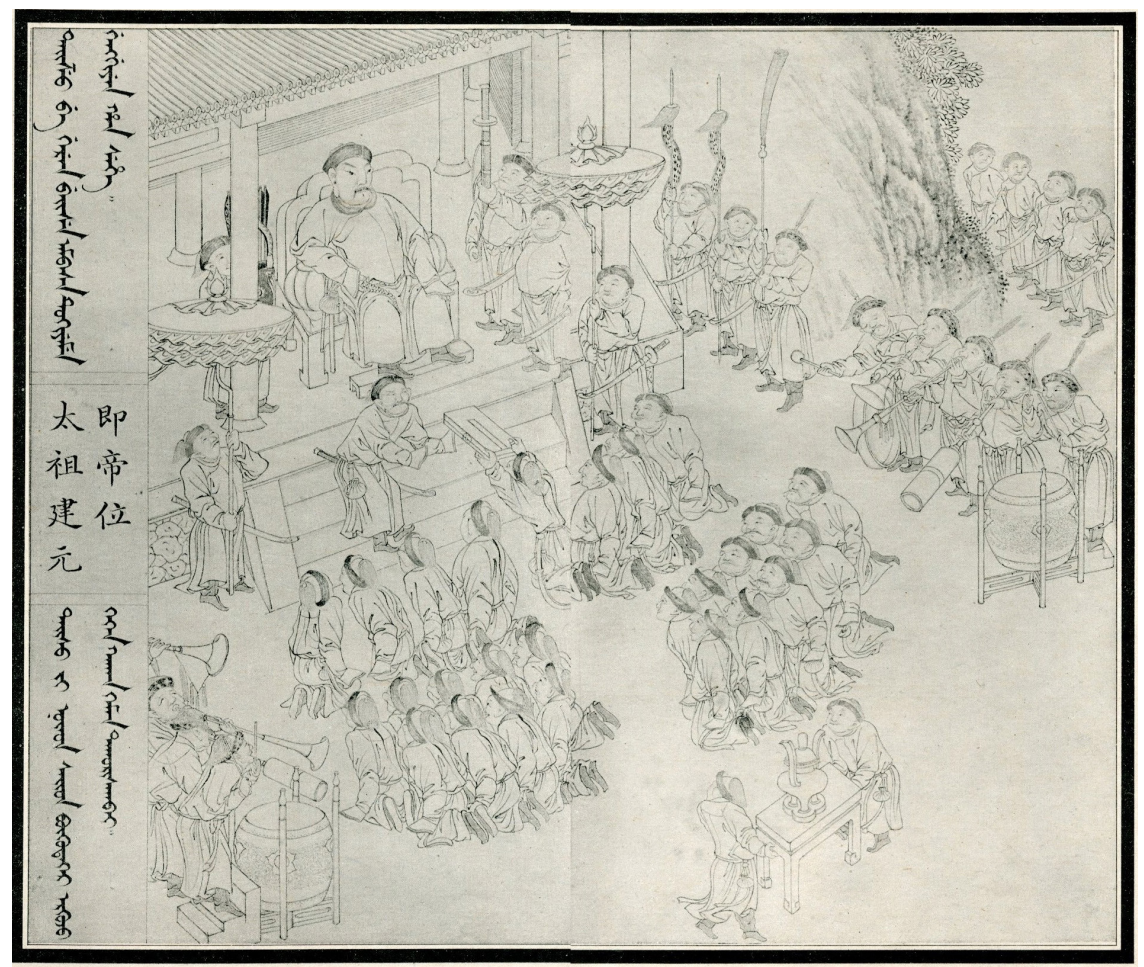

FIGURE 3. Nurhaci receiving the honorary title of Genggiyen Han of the Aisin Gurun in 1616. From Manzhou Shilu (Manchu Veritable Record), 1779. Manuscript, $26.2 \times 15.7 \mathrm{~cm}$. Korea University Library. Used with permission.

Being surrounded by the Ming, the Mongols, and the Chosonn, the future of the Aisin Gurun relied on how well they built relationships with these neighboring powers. When Nurhaci died, this daunting task was left to his son, Hong Taiji (1592-1643). When the new khan took the throne in 1627 , he immediately recognized that a serious crisis faced his country. The Manchu records describe the desperate conditions of the late 1620 : "The country had been starved ... so that people were even pushed to eat human flesh. The country had much silver but few commodities, because there was nowhere to conduct business." ${ }^{101}$ Hong Taiji himself had to confess in a letter to the Chosŏn king that his country was facing severe economic problems: "I have enough grain to feed my own people. But, as you may have heard, many Mongol princes, along with their people, are coming to follow me, fleeing from the misdeeds of [the Chakhar] Ligdan Han. There is not enough grain to feed all of these new subjects." ${ }^{102}$ This economic shortage pushed Hong Taiji to contact the Ming Ningyuan commander, Yuan Chonghuan (1584-1630), 
and to send the latter a stream of letters proposing the exchange of gifts. ${ }^{103}$ What he in fact needed was the resumption of the frontier markets, which he expected to follow from the gift-giving ceremony: "If Ming officials agree to make peace, we Jurchens, Han Chinese, and Mongols will collect ginseng and develop silver mines to trade with the Ming." ${ }^{104}$

Trade with the Ming was surely important for Hong Taiji, but it was a lesser issue than securing the territory of the Jurchen state. In 1627, Hong Taiji sent a letter of complaint to Yuan Chonghuan enumerating seven annoyances, three of which were related to Jurchen boundaries with Ming China. He emphasized that the Ming court had repeatedly violated the agreement of 1608 :

We agreed that if Chinese violate the boundary they should be killed, just as Jurchens stealing into Ming land are to be killed. ... However, in 1613, Chinese soldiers crossed the boundary to protect the Yehe and stationed themselves [in our Jurchen land].... In 1608, we agreed that those who tolerate trespassing are to be punished in the same way as the trespassers.... However, when we punished Chinese trespassers, the Ming, blaming us for killing innocent people, arrested our envoy and killed ten Jurchen people in revenge. ... Chinese soldiers burned the houses of Jurchen people and forced them to leave their land just before harvest. They also moved the stone marker standing at the boundary thirty $l i$ toward us, an action through which they could take that much land from us. They also plundered ginseng, furs, grain, and timber, all of which we Jurchens depend on for our lives. These are only the major grievances. How could I count all the minor problems? ${ }^{105}$

When Yuan Chonghuan insisted in his reply that all of the Liaodong fortresses and Han captives held by the Aisin Gurun should first be returned to the Ming, the khan's response was firm:

You [Yuan Chonghuan] say, "The khan should respect our Mighty Emperor to enhance his great grace and do his best to keep the peace at the boundaries." However, it is for you, not for other countries, to enhance the grace of your emperor. As for security at the boundaries, you control your territory, and we control ours. How could we control your territory? ${ }^{106}$

Later in the same year Hong Taiji reiterated to Ming officials who visited him, "A peace agreement between two countries should discuss boundaries, settling where the limits of your territory are and where those of mine are. Only after the boundaries are set can peace come." ${ }^{107}$ In his letters to Yuan Chonghuan, the khan emphasized that the Ming and the Jurchen state were physically divided and that each should respect and protect its own territory. As Pamela Crossley notes, Hong Taiji's emphasis on Jurchen territorial claims was related to his bid for "the credibility of the new khanate." He hoped that "the Later Jin and the Ming could divide the present Chinese territories, with the Ming presumably retreating from Liaodong and surrendering it to the jurisdiction of the Later Jin." ${ }^{108}$ In fact, Hong Taiji was enraged that the Ming had repeatedly violated the boundary agreement 
of 1608 made between his father and Ming officials, seeing the violations as evidence that the Ming did not acknowledge the sovereignty of the Jurchen state. For the khan of the Aisin Gurun, territory and sovereignty were inseparable.

In his letter to the Chosŏn king Injo (r. 1623-49) in 1634, the khan sought endorsement of the Aisin Gurun as a power independent of the Ming and asked the Chosŏn to persuade the Ming to recognize Liaodong as Aisin Gurun territory:

Recently I have several times tried to reconcile with the Ming, but they are now suddenly asking back the land of Liaodong [Liaoyang] and Guangning. Those people from Liaodong [Liaoyang] and Guangning whom heaven allowed us to rule and those Mongols who came to follow us are so numerous that our previous small territory cannot embrace all of them. ... It is out of the question for so many people to live together in a house or to be fed [within our previous territory]. The old Liaodong [Liaoyang], which the Ming is now asking to have back, is not even as good as their current land. Beijing is not only safe and comfortable, but also spacious. This is not an overstatement; I would just try to follow the right path [wangdao]. If you, Chosŏn king, agree with me and mediate a peaceful negotiation between the two countries [the Aisin Gurun and the Ming], how wonderful it would be! ${ }^{109}$

While negotiating the boundary with the Ming, Hong Taiji also sought to subjugate the Eastern Mongols. He finally acquired from the Chakhar the legitimate seal of the Mongol khan in 1636, when he ascended the throne of the emperor of the Great Qing (M. Daicing gurun), who ruled all of the Manchus, the Mongols, and the Han Chinese. ${ }^{110}$ By 1642, Hong Taiji, as the Chongde emperor, succeeded in his military campaigns against the Chosorn and the Eastern Mongols and subjugated all of Liaodong and the nearby Zhili Province to his rule. Once again, he proposed boundary making with the Ming. He demanded that the Ming exchange envoy visits, send gifts of ten thousand liang of gold and one hundred thousand liang of silver, and repatriate all Manchu, Han Chinese, Mongol, and Korean Qing subjects. He also proclaimed the specific location of the boundaries: "Your boundary is at Tuling between Ningyuan and Shuangshubao, and ours is at Tashan. Lianshan shall become a meeting place for trade between the two parties. If anyone from the two countries enters the area from the north of Tuling to the north of Ningyuan and Shanhaiguan, he should be executed." ${ }^{111}$ By this time it was obvious that the Qing emperor intended to claim the mandate of heaven, but before launching into China proper, the Manchu ruler first needed to complete his boundary making with the Chosŏn.

\section{THE CHOSŎN AND TRESPASSING}

It is not surprising that people other than the Jurchens longed for the precious ginseng. The high value of ginseng attracted Koreans to the Yalu and Tumen Rivers and Changbaishan, where trespassing was not easily detected. The Ming Chinese, 
the Jurchens, and the Koreans often trespassed in one another's territory. As a Chosŏn official reported in 1446, "The place where the Jurchens hunt and fish is within only two to three hours' walking distance from Chosŏn territory." ${ }_{112}$ There were occasional reports that Ming soldiers in Liaodong approached the Yalu River searching for ginseng and animals, but Chosŏn soldiers were instructed not to attack "Chinese [K. Tangin] ginseng collectors" or make any contact or communicate with them. ${ }^{113}$ However, they were also aware that "those intruders, if they find that Korean soldiers do not attack Han Chinese, may pretend that they are Han." 114 The Chosŏn court's obvious discrimination against Jurchen intruders reflects the hierarchical order between the Ming, the Jurchens, and the Chosŏn in the fifteenth century. Han Chinese, Jurchen, and Koreans all violated one another's territories, but their actions were treated unequally depending on who they were. More importantly, at this time, ginseng gathering in others' territories was generally overlooked as long as the intruders did not commit crimes or cause trouble. The Chosŏn policy was therefore aimed primarily at controlling the "northern barbarians," not at enforcing a general restriction at the frontier. If the Jurchens did not cause serious problems in Korean territory, the Chosŏn preferred to ignore their trespassing for the sake of peace.

Jurchen violations of Chosŏn territory increased during the sixteenth century. Kanggye in P'yŏngan Province reportedly became a no-man's-land that attracted many Jurchens in search of ginseng. There was a report about some Jurchen ginseng poachers who fought back with swords when they encountered Korean soldiers. ${ }^{115}$ Still, the Chosŏn court maintained the principle that Jurchen intruders should be treated carefully and not punished severely. In 1529 the court cautioned that "some Koreans on the frontier despise the Jurchen intruders and kill these ginseng poachers in the mountains. It is not an appropriate thing to do." ${ }^{116}$ It is clear, however, that not all listened to royal commands to treat the Jurchens well, for in 1548, this demand had to be repeated: "Jurchens entering Chosŏn land for ginseng gathering should not be randomly killed unless they cause trouble. . . . If soldiers take lightly the killing of innocent people, it may cause problems at the frontier." ${ }^{117}$

It was not until the late sixteenth century, when Nurhaci unified all the Jurchen tribes and emerged as a contender for control of Liaodong, that he began to complain about the cruel behavior of Chosŏn soldiers. In 1592, when several Jurchens were arrested for ginseng poaching and killed in unusually brutal ways, such as by beheading and skinning, Nurhaci was upset with this abuse of Jurchens at the hands of Koreans and protested to the Chosŏn court, threatening to bring the matter to the Ming authorities. Three years later, when a Ming Liaodong official and a Chosŏn interpreter visited Fe Ala, Nurhaci promised his visitors that he would impose stricter regulations on his people in order to discourage them from entering Chosŏn territory. In return, he requested that the Chosŏn do the same: "In the 
future, if any Jurchen intruder into Chosŏn land is arrested and sent alive back to us, we will execute him. But when we arrest a Korean trespasser in our territory and send him back to the Chosŏn, you should do the same. Then there will be no resentment between us." ${ }^{118}$

As the Jurchens became more powerful, they began to raise their voice to the Chosŏn concerning trespassing. It was the ginseng that grew at their frontier that continued to strain the relations between the Aisin Gurun and the Choson, especially once Hong Taiji took power. As the new khan put pressure on the Ming authorities in Liaodong, it became more difficult for Ming Chinese to steal into Jurchen territory to gather the precious root. In contrast, Koreans continued to cross the Yalu River in search of ginseng, which caused incessant trouble with the Aisin Gurun. The issue of illegal ginseng poaching was, in fact, not related solely to territorial violation. At this time, Hong Taiji was desperate to open trade with the Chosŏn, because the Jurchens were blockaded from accessing Ming markets as punishment for their offensives against Ming fortresses in Liaodong. The Jurchens needed the Korean market, where they could exchange various products, including ginseng, for products from China as well as from Korea. Therefore, Hong Taiji's efforts to stop Koreans from poaching ginseng in his territory were aimed at both the establishment of Aisin Gurun boundaries and the protection of the Jurchen ginseng trade.

Jurchen-Chosŏn relations were aggravated by the Ming general Mao Wenlong, who was stationed with his army on an island belonging to the Chosŏn. Mao's soldiers enticed Ming Chinese farmers in Liaodong to escape from the Jurchens, which posed a serious threat to Hong Taiji, who planned to build an agrarian state in Liaodong. Mao's presence in Korea also indicated the perpetual respect of the Chosŏn for the Ming court and, simultaneously, its hostility toward the Aisin Gurun. ${ }^{119}$ Only a war could solve these problems. On February 23, 1627, in the first year of his reign, Hong Taiji ordered his cousin, Amin, and other princes (M. beile) to lead armies to Korea to defeat Mao Wenlong. ${ }^{120}$ Two months later, the Chosŏn court surrendered to Amin and promised a treaty of brotherhood with the Aisin Gurun. By establishing an official relationship with the Chosŏn, Hong Taiji could expect to receive an annual tribute and gifts, as well as the opportunity to finally open regular trading markets (K. hosi) with the Koreans.

More importantly, the first military campaign of 1627 empowered Hong Taiji to make further complaints about Korean trespassing. In 1628 he issued a warning to the Chosŏn king: "It should be thoroughly prohibited for people from the two countries to cross the boundary at will." ${ }^{121}$ Under such pressure from the Aisin Gurun, the Chosŏn court had to punish Koreans stealing into Jurchen territory. In 1631, two Koreans collecting ginseng on Jurchen land were executed in Seoul in the presence of Hong Taiji's envoy. ${ }^{122}$ Korean trespassing provided the khan with a good excuse to accuse the Chosŏn on other contentious issues, such as the poor 
conditions at the trading markets and the maintenance of Chosŏn relations with the Ming. Markets at Zhongjiang (K. Chunggang) were not producing as much profit as Hong Taiji had anticipated because Korean traders, afraid of being bullied by Jurchen visitors, were not willing to come to them. The Chosŏn court also continued to acknowledge and serve the Ming as the superior court, with no apparent intention of changing their long-established relationship. In addition, Hong Taiji was not satisfied with the amount and quality of Chosŏn tribute and gifts for his court. ${ }^{123}$ As his relations with the Chosŏn court were generally not progressing as he had expected, Hong Taiji made Korean trespassing into a bigger issue in order to impose more pressure on the Chosŏn court. Korean ginseng collecting in Jurchen territory could certainly have been treated as minor trespassing, but the khan wanted to discipline the Chosŏn and therefore turned these infractions into serious crimes.

In the 1630s, discussions between the Aisin Gurun and the Chosŏn were all about Korean trespassing for hunting and poaching, low ginseng prices, and slow trading. In 1633, Hong Taiji sent Inggūldai and Daisongga with two hundred jin of ginseng to trade in Korea. Bringing eighty people with them, Hong Taiji's envoys asked to open a market "in order to borrow grain from Korea." ${ }^{124}$ In the same year, Hong Taiji blamed the Chosŏn for lowering the ginseng price from sixteen to nine liang per jin, adding complaints about the constant intrusion of Koreans into Aisin Gurun territory:

[All of these intruders] escaped your country and entered our territory. Only some of the cases have been reported to me. Who knows how many Koreans are trespassing on our land? You have broken your promise to us and let your people come into our land to collect ginseng and hunt animals. Your country is also full of animals, but were any of our people stealing into your land to get them? ${ }^{125}$

To prevent further Korean intrusions, Hong Taiji decided to push the Chosŏn court to punish not only intruders but also local officials administering the area in which the trespassing had occurred. In 1635, when thirty-six Koreans in Wiwŏn were arrested for poaching ginseng on Jurchen land across the Yalu River, Hong Taiji insisted that the Korean prefect and other local officials should also be jailed. While the Chosŏn court officials were anxiously defensive, arguing that local officials had never been disciplined for trespassing before, the Chosŏn king, who wanted to avoid the Jurchen khan's reprimands, agreed to punish the local administrators for negligence of their duties. ${ }^{126}$ Gradually, the Chosŏn lost its power to argue its case regarding trespassing. The Chosŏn king Injo could only ask for pardon when Hong Taiji blamed Koreans for constantly stealing into his country: "It is a pity that our [Chosŏn] people have sought ginseng profits and violated boundaries. From now on I will surely impose strict regulation to eradicate such crimes." While asking for Hong Taiji's forgiveness, Injo also bribed the khan's envoy to repatriate the Korean trespassers who were held. ${ }^{127}$ In Injo's language, there 
was no longer any trace of dismissing Jurchens as "wild people" or as uncivilized barbarians who Koreans once believed deserved to be killed or skinned.

\section{GINSENG FOR QING MANCHUS}

As the Jurchens asserted their right to rule Liaodong, the significance of ginseng evolved. In addition to being a valuable commodity and a physical indicator of Jurchen territorial boundaries, ginseng also became a unique symbol of Jurchen identity. ${ }^{128}$ Ginseng, along with pearls and furs and as a gift equivalent to gold, silver, and silk, was often sent as an official gift of the Aisin Gurun to foreign rulers and envoys. In 1627 Hong Taiji suggested in his letters to Yuan Chonghuan that "we [the Aisin Gurun] would send ten tana pearls, one thousand sable pelts, and a thousand jin of ginseng to the Ming; the Ming would return ten thousand liang of gold, one million liang of silver, a million bolts of silk, and ten million bolts of cotton linen." ${ }^{129}$ Ginseng was also sent to the Chosŏn court as a gift from the khan. Even while blaming Koreans for poaching ginseng in his country, Hong Taiji presented the coveted root to the Chosŏn envoy who was visiting his court to discuss Korean trespassing. ${ }^{130}$ These actions show that Hong Taiji considered ginseng not only a special resource growing in Jurchen territory but also a symbol of the Jurchens themselves. This view reinforced the idea that non-Jurchens should not be allowed access to it. As the Aisin Gurun continued to expand its territory, its neighbors, especially the Koreans, were further restricted from collecting ginseng and trespassing was even more severely punished. The Jurchen monopoly on ginseng, Hong Taiji believed, would be firmly ensured only when the Jurchens succeeded in establishing the superiority of their status vis-à-vis the Chosŏn and in preventing Koreans from approaching their ginseng and their territory at all.

Ascending the Qing imperial throne and renaming his people the Manchus, Hong Taiji, now the Chongde emperor, formally announced his intention to challenge Ming supremacy. He first sought to enhance his status by transforming his relationship with the Chosŏn, the neighbor with whom he had had so many disputes over trespassing, captive repatriation, annual tribute, and trade. Above all, the Chosŏn court's official recognition of his imperial authority would constitute important political capital for the Qing in waging war against the Ming. To attain such recognition, military action was inevitable. ${ }^{131}$ On December 29,1636 , the Chongde emperor himself led armies to attack Korea, and in less than two months the Chosŏn court surrendered to him without condition. ${ }^{132}$ Following the military success, the Qing was able to impose an onerous and humiliating peace treaty upon the Chosŏn. The Chosŏn had to end its relationship with the Ming and instead use the Qing title in its official documents and receive the calendar issued by the Qing court. Chosŏn royal princes and high officials' sons were also to be sent to Shenyang as hostages. In the event of future Qing attacks on the Ming, the 
Chosŏn was required to provide soldiers and weapons for the Qing. The Chosŏn must send tribute embassies to the Qing court for the emperor's birthday, the New Year, and the winter solstice, among other occasions. These embassies were to follow the same regulations as those observed when visiting the Ming court. Runaway captives were to be sent back to their Manchu owners. The Chosŏn could no longer trade with the Uriangkha Mongols in Liaodong but were allowed to continue to trade with Japan. In addition, the Qing made a long list of specific items-gold, silver, furs, tea, dye, paper, cotton fabrics, and grain, among othersthat the Chosŏn court was to present to the Manchu emperor. ${ }^{133}$

There was one significant omission in the Chongde emperor's list of required gifts: it did not include Korean ginseng, which had been the most important item in Chosŏn tributes to the Ming emperors. Among the various rulers in China, the Ming court was the most eager to receive Korean ginseng; the court even listed ginseng as one of the Korean tributes in the Statutes of the Great Ming Dynasty (Da Ming huidian). Given that the Jurchens occupied most of the ginseng-producing area, Korea was the most reliable provider of ginseng for the Ming court. Indeed, throughout the Ming period, the best-quality Korean ginseng was carefully selected and sent to Beijing. ${ }^{134}$ The omission of ginseng from the Chosŏn tribute to the Qing court did not mean that Chongde had no interest in this precious root. On the contrary, not requesting Korean ginseng emphasized that the Manchus did not consider ginseng a local Korean product, a specialty of a vassal's domain (fangwu). As James Hevia explains, a local product paid as tribute, as regulated in the Qing imperial guest ritual, was in fact "a means for differentiating one domain from another." ${ }^{135}$ Unlike the Ming court, which had considered ginseng a unique local product of Korea, the Manchus saw it as a product of Manchu lands and a symbol of the Manchu people. In addition, as a fangwu symbolizing the division of distinct domains, ginseng, the Manchu product, indicated Qing separateness from the Chosŏn. Ginseng was defined as a local product of the Manchus, and therefore, the Chosonn presentation of ginseng in tribute was no longer accepted.

After the second military campaign of 1637, Korean transgressions and ginseng poaching evoked even harsher criticism from the Qing court. The Chosŏn prince Sohyŏn (1612-1645), who was held hostage in Shenyang, received frequent complaints from Manchu officials about Korean trespassing and the poor control of the Chosŏn over their boundaries. ${ }^{136}$ In 1645, when local people from Kanggye in P'yŏngan Province were arrested for crossing the Yalu River into Qing territory to poach ginseng, the Qing envoy went to Pyŏngyang and took a local Korean official there into custody, putting him in a cangue. ${ }^{137}$ It became a regular rule that Korean intruders, arrested for trespassing and poaching ginseng in Qing territory, would be beheaded on the shore of the Yalu River and, in addition, that local officials in the responsible Korean district would be dismissed or banished. ${ }^{138}$ 
In 1642, the Chongde emperor may not have anticipated that within two years his son would enter Beijing to rule China proper, but he was well aware of the territorial limits of his country:

I have succeeded to the great enterprise of Taizu and ascended the throne with heaven's help. All the people living from the eastern sea to the northwestern sea have been subjugated, including the tribes of Dog Keeper [Shiquan] and Reindeer Herder [Shilu], and those who make their living by fishing and hunting, not through agriculture, in the region where black foxes and black sables live; the Oirats [E-lu-te] and others who live far away near the origin of the Onon River. The Mongols and the Chosŏn have also been incorporated $[\mathrm{ru}$ bantu $] .{ }^{139}$

After the war of 1637, the two countries continued to deal with trespassers, most of whom now came from the Qing side into Chosŏn territory. Facing the aggressive Qing expansion, the Chosŏn king insisted that Chosŏn territory should be respected. Injo pleaded with the Qing to do something about disturbances caused by Qing soldiers and civilians within Chosŏn territory that Chosŏn authorities were finding difficult to control. Injo's conciliatory 1641 request to the Chongde emperor was markedly different in tone from Sŏnjo's condescending letter in 1592 asking Nurhaci to stay within his limits:

Even though this small country [the Chosŏn] is deemed by the great court [the Qing] to be as close as a family, it is also true that each has its own territory. These days it is necessary to check people coming and going, whether or not they possess written or spoken permission, because otherwise arbitrary crossings and trade get out of control. If [trespassers] are not firmly curbed now, territories [K. kangyŏk] will not be clearly fixed and the towns within them will not be stable. If crossing [the rivers] were prohibited except for those having an official document and proof, we believe that local people will be relieved and future problems prevented. ${ }^{140}$

In the same way that Nurhaci had underlined the significance of territorial limits in order to protect his fragile Jurchen state from the neighboring Ming and Chosŏn, the Chosŏn king Injo stressed the boundaries that divided his kingdom from Qing lands in order to protect Chosŏn territory and authority. Just as the emerging Jurchen power had wanted to defend its land from the great Ming, the tributary Chosŏn court now sought to distinguish its territory from the suzerain Qing empire. All of these calls for respecting boundaries and sovereignty were efforts to survive the severe competition around Liaodong in the late sixteenth to early seventeenth centuries.

Ginseng carried high economic, political, and cultural value during the period of transition from the Aisin Gurun to the Qing empire. During the Jurchens' initial rise, ginseng was one of the most valuable commodities from which Nurhaci made 
the huge profits that enabled him to consolidate his power. In the second stage, when Nurhaci had succeeded in unifying the Jurchens and began to challenge Ming power, ginseng gradually came to be used for the purpose of indicating the territorial boundaries between the Ming and the Aisin Gurun. In the third phase, once Hong Taiji ascended the throne, ginseng came to bear a more political significance in foreign relations. Hong Taiji attacked Korea in order to achieve two goals: the economic goal of protecting ginseng profits from Korean intruders, and the political goal of enhancing the position of the Qing state as a contender for control of Liaodong. However, the tributary relationship, established as the result of the military campaign of 1637 , failed to resolve permanently the perennial challenges of sharing natural resources near the Yalu and Tumen Rivers. Despite two devastating wars, Koreans soon resumed the practice of crossing the rivers to collect ginseng. Throughout the Qing period, the Manchu rulers had to renegotiate their tributary relationship with the Chosonn, which required them to maintain the borderland with the Chosŏn, as discussed in chapter 2 . 